\title{
The Influence of Islam and Javanese Culture on The Meaning of Keraton Surakarta Hadiningrat's Architecture
}

\author{
Ihdina Sabili, Murni Rachmawati, and Purwanita Setijanti \\ Department Architecture, Institut Teknologi Sepuluh Nopember, Surabaya \\ e-mail:ihsabil11@gmail.com
}

\begin{abstract}
The effects of religion and culture to the people's life in Indonesia certainly become inevitability. Keraton, as the residence of the king and the family has philosophical concepts and meanings on each element. Keraton Surakarta in physically and principle adheres to the philosophy of the Javanese people's life as a media of Islamic development as well as the Javanese culture. This study aims to find out the influence of Islamic values and Javanese culture on the architecture of Keraton Surakarta, especially on the philosophical meaning. The research paradigm used in this study is the Inter-subjective Paradigm. The method applied is Combined Strategies, between Historical Research and Qualitative Research. The data collection was obtained through the literary study, observations, and interview of Keraton Royal Family and The Servants. Research conclusions came from verifying data with interpretation and historiography on the research object. The result of this study is the architectural significance of Keraton Surakarta applying islamic values combined with Java 'cultural philosophy especially to the building orientation and layout sequences. Imprinted meaning derived from the core of the value of human's relationship with god and the courtship philosophy of the Manunggaling kawula gusti.
\end{abstract}

Keywords-Islam, Javanese Culture, Keraton Surakarta, Meaning Architecture.

\section{INTRODUCTION}

$\mathrm{I}_{\mathrm{d}}^{\mathrm{s}}$ NDONESIA, as a nation of diverse cultures, certainly has diversity in characteristics and architectural shapes. Culture enters through various aspects of the same region, whether through social, political, or religious. Said agil husein (2002:1) notes that in cultures there are some unique traits. Among these forms a new cultural pattern that combines all cultural elements into a value and normal configuration that adheres to people's thoughts and behavior. There is a distinct culturally, to form a cultural pattern in such cultural focus as values combining all cultural elements into an institutionalized cultural configuration, values or norms that imbibe and adhere to people's thoughts and conduct [1].

On the island of Java, Keraton Surakarta hadiningrat is one of the national cultural centers. Especially Java or jawi culture. Keraton Surakarta is part of a cultural inheritance from Keraton pajang to mataram kotagede and then to kartasura until finally in Surakarta. Cultural values inherited from generation to generation in community life are a source of views and orientation of the life of the people of Surakarta in particular and Javanese society in general [2].

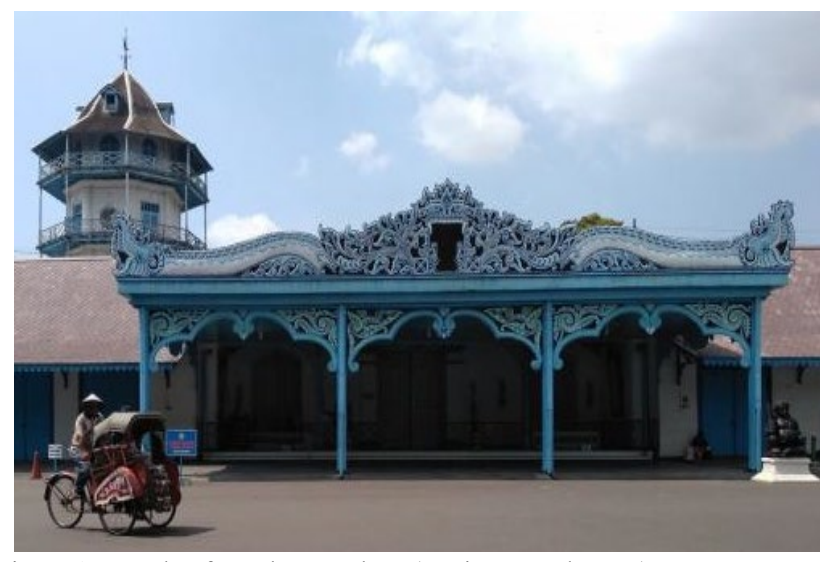

Figure 1. Facade of Surakarta Palace (Kori Kamandungan)

Among the few influences in the world contributed to some of Keraton's architectural elements. First as successor to the islamic mataram kingdom, Keraton Surakarta carries the traditional islamic faith and responsibility to pass it on to people in her domain. Then the second was the Javanese culture. Keraton Surakarta, located in the city of Surakarta, an island city of Java that is the hub of culture. The existence of Surakarta Keraton has become a model for Surakarta society in many ways. Of beliefs regarding the philosophy of life, of ideas and teachings held by Keraton [3]. The symbol is as shown in the following image.

The selection of a Surakarta Keraton object hadiningrat is based on a solid historical factor as evidence of developments in Islam on the island of Java. This Keraton is an important part of the history of the islamic empire of mataram as revealed by Heniy Astianto (2006:353). Keraton Surakarta also serves as a traditional traditional center for traditional conservation in Java and is still needed in the cultural environment of Java. There are some researchs with nearby discussions but have not yet reached accurate topics with more detailed and specific data.

Based on this phenomena, it is known that it is important to examine the influence of Islam on the Surakarta Palace. This research is looking for the values of Islamic life and Javanese cultural philosophy that applied at the Palace as evidence of historical objects and architecture. The formulation of the problem that must be answered is first about the value of Islam and Javanese culture contained in the Surakarta Hadiningrat Palace. Second is the meaning of the Surakarta Hadiningrat Keraton architecture. And then certainly the influence of Islamic values and Javanese culture 
The $6^{\text {th }}$ International Seminar on Science and Technology (ISST) 2020

July $25^{\text {th }} 2020$, Institut Teknologi Sepuluh Nopember, Surabaya, Indonesia

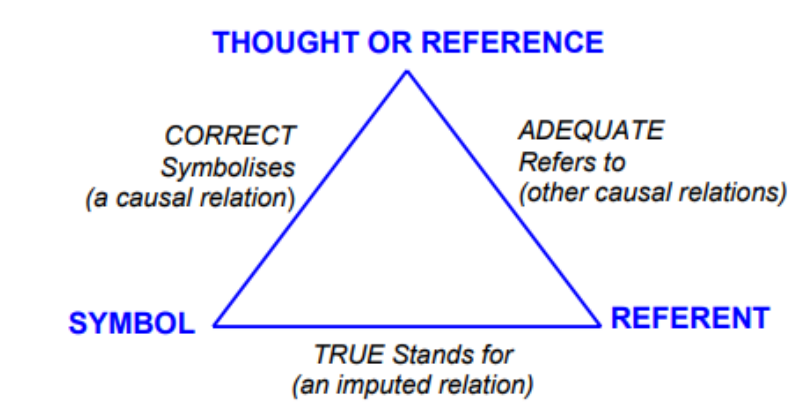

Figure 2. Relation of Symbol and Reality

affect the architectural meaning of the Surakarta Hadiningrat Palace can be determined. The purpose of this study research is to know the Islam value, Javanese culture and its influence in the meaning architecture of Surakarta Palace. The theoretical benefit of this research is to giving academic contributions to the historical phenomena of cultural. And the practical benefit is to be a consideration for the decision making of wisdom in harmonizing between islamic values and Java in development of a Keraton Surakarta.

\section{THEORY}

In spreading Islam in the Java region, walisongo used a slow and gradual method, without sternly rejecting the culture of Javanese society. Islam introduces tolerance and equality. In Javanese Hindu society which emphasizes differences in degrees, Islamic teachings on equality are interesting for Javanese people. Islam as a religion and value system that is transcendent, throughout its history has helped its adherents to understand reality which in turn embodies certain patterns of life. In this context, Islam acts as a subject that determines the course of history, which gives rise to changes and continuous accommodation of views and patterns of life.

There are seven cultural elements that can be found in all the nations of the world: language, knowledge systems, social organizations, gear and technology systems, livelihood systems, religious and artistic systems. The architecture and sculpture found therein are part of living equipment and technology and art systems [4]. Prof. Dr. Koentjoroningrat in his book, Javanese Culture (2005) said that culture consists of two main components, namely content and form. Meanwhile, the form of culture consists of cultural systems (ideas and ideas), social systems (behavior and actions), and physical culture (facts and objects of material culture).

In broad outline, Javanese culture can be divided into two parts, physical and spiritual culture. Born culture is related to one's position as an individual creature and social creature. In that case, Javanese culture has rules that can be easily identified based on cultural expressions as the manifestation of cultural values supported by the community. On the contrary, the inner culture is related to problems that are supernatural or things that cannot be reached based on empirical or objective calculations.

Inner culture according to Koentjoroningrat in Prabowo (2003: 25) included in the classification included in the Javanese religious or religious system symbolized in the expression of paran or manunggaling kawula-Gusti in Javanese religious views. Meanwhile, born culture is seen in

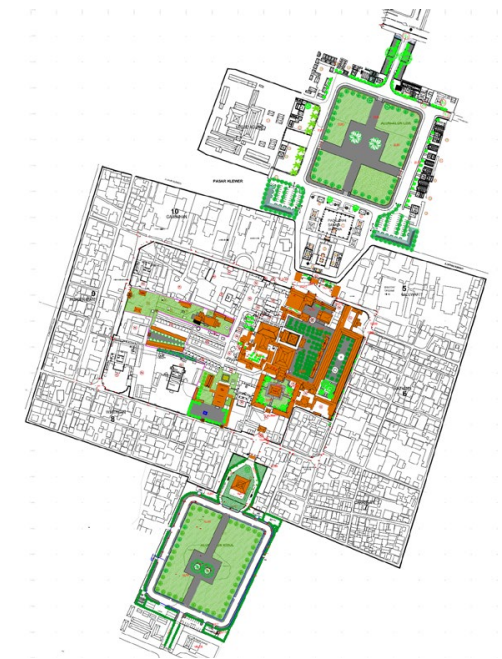

Figure 3. Layout of Surakarta Palace

the symbolization of ethical values that guide Javanese people in acting in accordance with their nature. Both as individual creatures and social beings. Individually, Javanese people need to stay on the path of life that strives to reach the main human level so that they can reach the ultimate composition of 'perfection of life' as a manifestation of virtuous beings. As is the case with Indonesian culture, it has experienced cultural dualism, the first is the culture of the Palace and the second is popular culture. In both types of culture, it has gained the influence of Islam which is evidence of acculturation between local culture and Islam.

Architecture in any era will always be associated with form, content and expression. That is a special way of culture articulating content and expression. Architecture is the creation of atmosphere, use marriage and image. Not in the luxury of materials or high technology lies the price. [5]. Every consideration in the architectural categories is always inevitable and always includes three Vitruvius categories, which Sir Henry Wotton said: "Well building hath three conditions: Firmness, Commodity and Delight." David S. Capon (1983) says that since the days of the Roman Empire, these three categories have surprisingly experienced little change. These three categories are Form, Function and Meaning.

Architecture as a space for the location of human life, not just physical, but also involves the institutions of basic habits. These institutions include, among other things, the social and social arrangements that are accommodated and influence architecture. Meaning is the content or purpose of the speaker or writer. The intended meaning is a form of the content of the message delivered. Meaning is the meaning or purpose which is drawn from a word, so the meaning with the object is closely interlocked and united.

The most basic idea of semiology and meaning in architecture is the idea of any form in the environment, or sign in the language, motivated, or capable of being motivated. This helps explain why all forms suddenly become more alive or become pieces [6]. Rapoport also defined meaning in architecture. Meaning can be perceived by a person, then the person will react to his environment globally and objectively before undertaking more in-depth analysis and evaluation. First, one can feel the material, then the 
The $6^{\text {th }}$ International Seminar on Science and Technology (ISST) 2020

July $25^{\text {th }} 2020$, Institut Teknologi Sepuluh Nopember, Surabaya, Indonesia
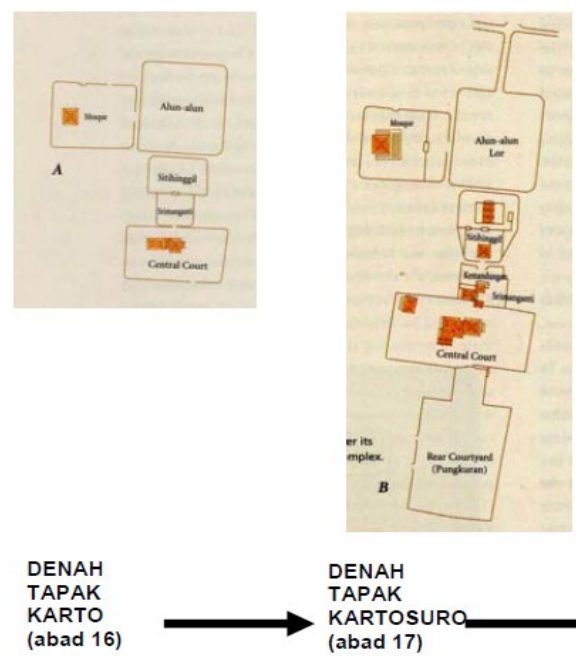

DENAH

KARTOSURQ

(abad 17)$$
\text { (abad 16) }
$$
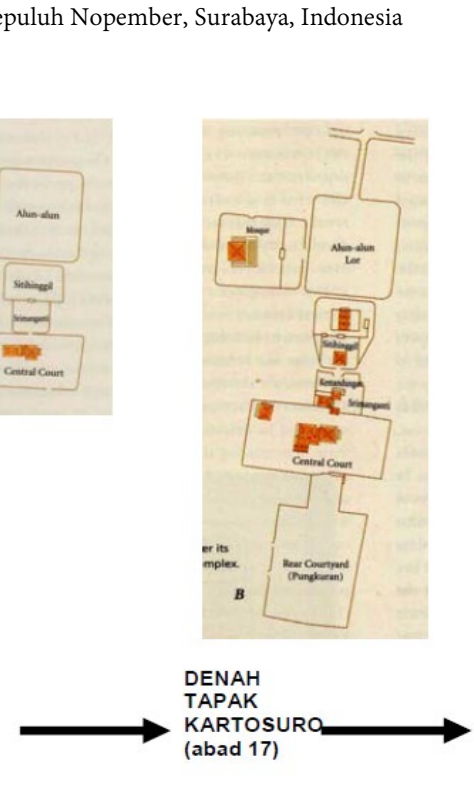

Figure 4. Development of Surakarta Palace

second is the function, and the next is the meaning of an built environment.

Eco (1980) says the architecture can be viewed as a system of meaning. Ogden and Richard (in eco, 1980) applied a three-semioth facet to architecture. The three points are the symbol, thought or reference, where agreement and referent are the physical realities in which the symbol refers indirectly. According to Ogden-Richard, the signifier (symbol, word of architectural form) connotes signified (concepts, thoughts and contents) and may or may not denote objects (referents), objects, or "actual functions" in architecture [7].

As stated by Rapoport, that meaning in architecture is a person's perception of the reaction to their environment globally and affective. Capon also revealed that the essence of an architecture is about its form, function and meaning. Especially if it is associated with the history of a Palace as an important part in the development of Islam. The existence of the Surakarta Palace has become a role model for the Surakarta people in various ways, both from beliefs about the philosophy of life to understandings and teachings embraced by the Palace. Surakarta City is a city that grows as the center of a royal government, which then develops into a city that supports commercial, industrial, service and other sectors, like a modern city [3].

Keraton Surakarta has a distinctive spatial concept in the layout. There is a strong concept of symbolism and philosophy in the Surakarta Palace, so there is a hierarchy in the arrangement of buildings in the Surakarta Palace. The concept of symbolism and philosophy of the Keraton Surakarta is also found in the outer space which is divided into four criteria, namely Alun-alun Lor, Setinggil Lor court, Kedathon court and Alun-alun Kidul. The square in the north is a symbol of life in the world and the square in the south reflects death [8].

Maruti in Febyandari (2012: 9) explained that in the middle of the North and South Alun-alun there is a main area of the Palace that is surrounded by two meters thick walls and six meters high called the Baluwerti area. In the middle of
Baluwerti there is still a wall fence around. On the inside of this wall lies the core of the Palace which is often called Cepuri or Kedaton. In Kedaton there is a residence of the king with his family. The king lives in a building called Dalem Agung Prabasuyasa.

The limits that are used to observe the Surakarta Palace are not merely forms and functions, but things that intersect with values, meanings and meanings, as reflected in the Paku Buwono X expression as follows: "Karaton Surakarta Hadiningrat, haywa kongsi dinulu wujude wewangunan kewala, nanging sira padha nyumurupana sarta hanindakna maknane kang sinandi, dimen dadya tuntunan laku wajibing urip hing dunya tumekeng delahan." Meaning: Do not the Surakarta Hadiningrat Palace only be seen from the form / shape of its physical building, but it should be known, understood and carried out the meaning of the messages implied and written, so that it can be a guide to carry out the obligations of living in the world and the hereafter.

\section{METHODOLOGY}

The paradigm used in this study is the Intersubjective paradigm when referring to the book Architectural Research Method by Groat and Wang. That is, this research puts forward the values of actions and interpretations of the meaning of people on an environmental scale, including how these transactional relationships are in a larger social or historical context. The speakers as the owner of interpretations of meaning here are the users and observers of the object. This paradigm assumes that empirical realities occur in a socio-cultural context that are interrelated to one another. Therefore every social phenomenon is expressed holistically.

In this study, using the Combined Strategies method, which is a combination of Historical Research and Qualitative Research. This is because in this research process focuses on objects in the past, then analyzes them with conditions in the past until now. This study also intends to critically examine and analyze the recordings and relics of an 
The $6^{\text {th }}$ International Seminar on Science and Technology (ISST) 2020

July $25^{\text {th }}$ 2020, Institut Teknologi Sepuluh Nopember, Surabaya, Indonesia

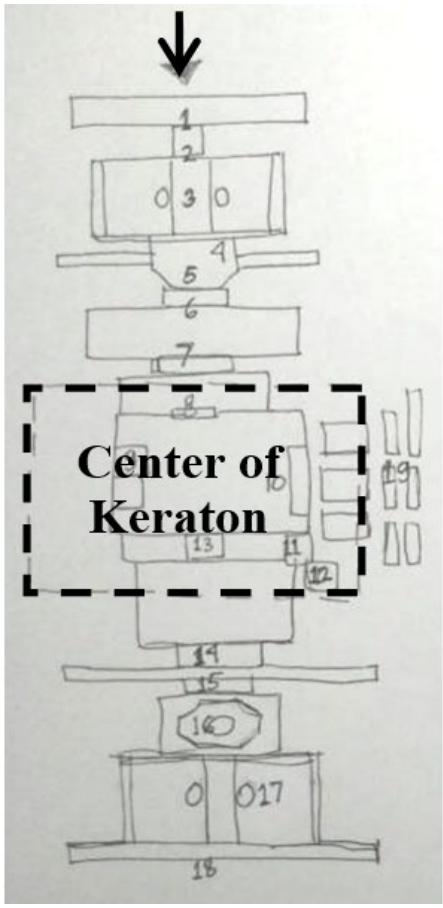

Figure 5. The order of Keraton area

event in the past. Types of factors are taken based on objects that have been present since the past [9]. The combination model uses type A Dominant-Less Dominant Design, which is a model with one of the more dominant methods. The more dominant method is Qualitative Research, and the method that is less dominant is Historical Research.

In this study, several data collection techniques were used which were divided into two, including primary data and secondary data. The resource persons who were the object of the interview consisted of three people. The first speaker was from the core family of the Surakarta Palace, namely Gusti Moertijah, the younger brother of King Pakubuwono XIII who was ruling. The second person who was the source of this research material was Mr. Suwardi, he was one of the observer teams from the architect of the Surakarta Palace. The last speaker who was the object of the interview was Kanjeng Yoes, one of the Palace's senior courtiers who also still had blood relations with families in the Palace.

All results are compiled as a collection of various information to describe conclusions and take action. The next step is drawing conclusions based on findings and verifying data. Basically the initial conclusions that have been obtained are still temporary and these conclusions will change if the discovery of evidence that supports the next stage of data collection. This process of obtaining evidence is what is meant by data verification.

\section{RESULT AND DISCUSSION}

Surakarta Keraton established in 1745 experienced a period of development over a period of time. The construction and repair work went on from Sultan Pakubuwana II to Sultan Pakubuwana XII to the physical entity that Keraton existed today. From the north square through the gladag arch to the south square through the ivory

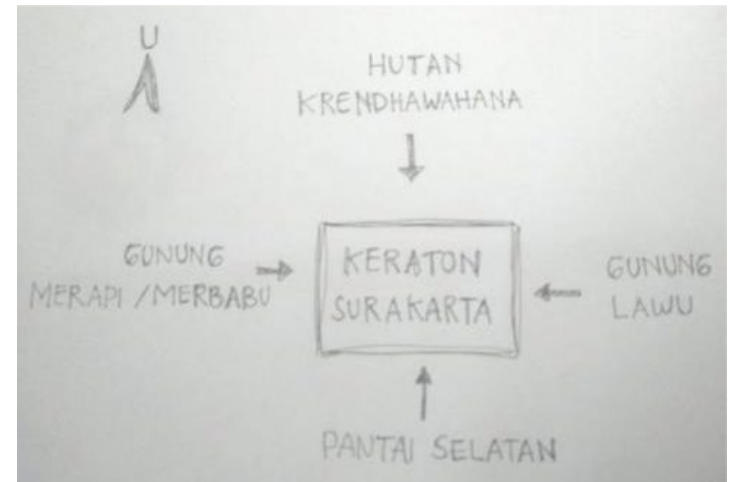

Figure 6. Keraton's position as an axis

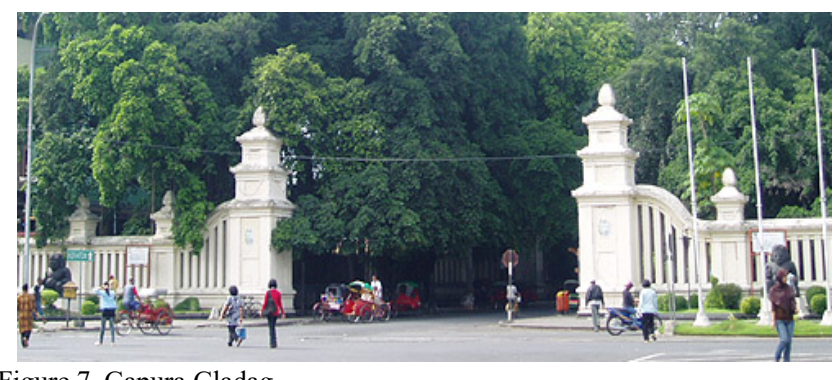

Figure 7. Gapura Gladag

arch. The building of a new Surakarta Keraton started with a building design not far from the kartasura Keraton. The new Keraton was completed in 1745 although Keraton still had no fences with walls like today.

The development of Surakarta Keraton can be seen in every century. Starting from the first one was still in Karta in the 16th century. Then in the 17th century it moved to Kartasura with an additional area to add the south square. Keraton was transferred to Surakarta in the 18th century with an uncomplex composition. Still made up of Keraton's core components, including pendhapa Pagelaran, Sasana sewaka and other parts of the baluwerti. In the 20th century, the Keraton area became more prevalent with settlements surrounding baluwerti.

The concept and philosophy of each element of the Palace has an influence from each phase that is passed. This results in the shape and style of the Surakarta Keraton building. In the building style and style used by the Palace there is an influence from the western architectural style brought by the Dutch like the shape of a pillar. The elements of Chinese architecture brought by Chinese traders and Arabic-style who entered because of the presence of the Arabs in Solo. However, the traditional Javanese architectural style is the basis of the form and philosophy of the building at the Surakarta Palace [1].

The Keraton Surakarta landscape arrangement applies the concept of cosmology which is influenced by Hinduism and Buddhism. Dumadi (2011) states that Javanese people formulate human life in two cosmos (nature) namely macrocosm and microcosm. Macrocosm has an understanding that the universe is a container that remains large and has great power. While the concept of microcosm has an understanding that the king is the embodiment of God in the world so that in the king there is a balance of various 
The $6^{\text {th }}$ International Seminar on Science and Technology (ISST) 2020

July $25^{\text {th }}$ 2020, Institut Teknologi Sepuluh Nopember, Surabaya, Indonesia

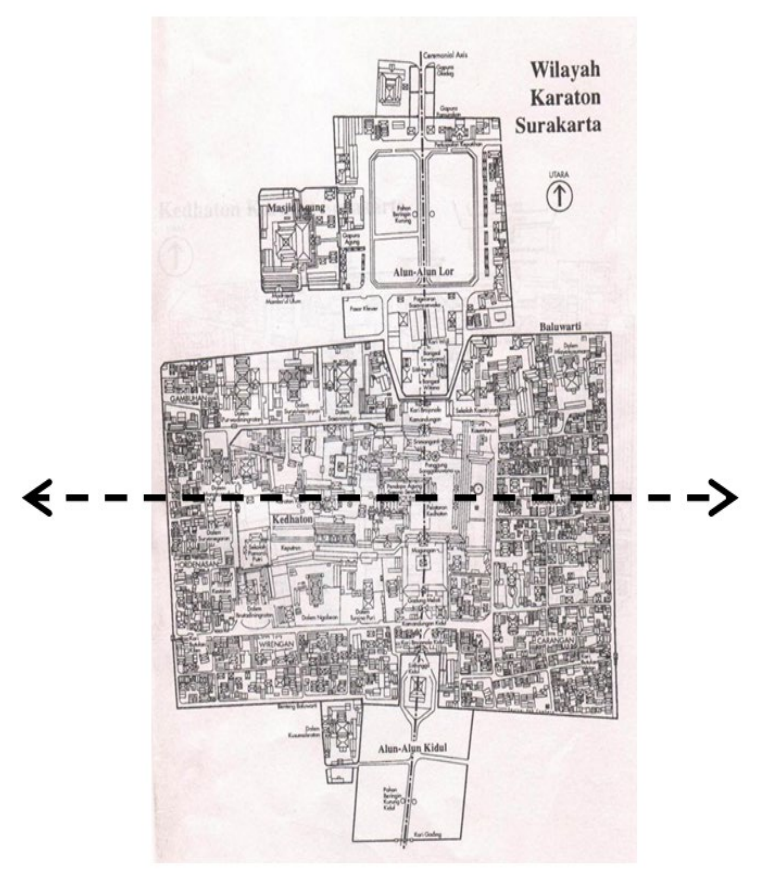

Figure 8. Line of symethrical concept

natural forces. In the concept of microcosm, the king is the center of life in the world and the Palace as the residence of the king.

The buildings in Surakarta Palace are actually a philosophy of guidance to achieve the perfection of life. The overall order of the Palace and its layout is a way of life for the Javanese people. Because each part has a philosophical meaning that can be applied to life. This further strengthens the influence of the interrelationship of Islamic values which results in the essence and philosophy of Javanese culture on the meaning of the architecture of the Surakarta Palace.

1. The order of the Keraton area from the north (the gladag arch) to the south (the ivory arch) as mankind's relationship with the god known as hablu minallah. It shows that when man walked from the entrance to the center, he meant man's journey toward god. Shows a human being born to death.

2. Keraton's position as an axis from the north-wet-west side refers to the concept of the beacon papat kalima pancer. Which is the concept of man with himself (man has 4 friends in him; Amniotic fluid, placenta, blood and umbilical cord.) The human conception with its god is that every human is being watched by four angels round about. With god's central axis.

3. Gapura gladag is the beginning of the Keraton area. Gladag gives meaning to the slaughter of game animals. It's human beings who start the journey that should trim the animal first.

4. Several elements in the Keraton are created in pairs, as are public squares, kori kamandungan, kori wijil to the arch. Meaning everything in this world is created in multiple pairs. It means that human life is not independent of two contradictory things. Therefore, understanding Java 'philosophy of life must be patient and receive.

5. Sitihinggil, siti means ground, hinggil means high. So the ground you tread on is higher than the common people.

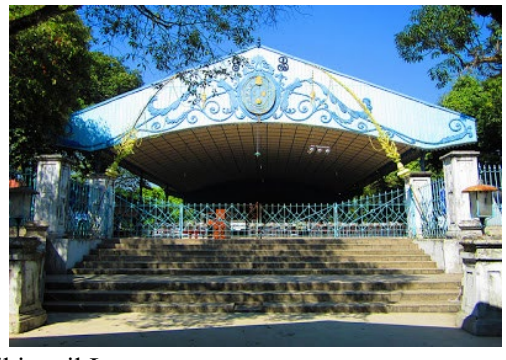

Figure 9. Sitihinggil Lor

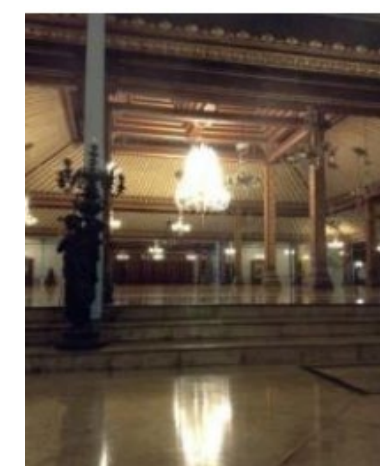

Figure 10. Sasana Sewaka's Interior

You control your lust, you have reached a level of gratitude, and have understood the rules of the law, and you know the concept of god. It has done its job in the world.

6. Sasana Sewaka is the king's throne room. Has a sense of peaks, an area the shaft of Keraton. It means the place facing the last of god.

The order of the Keraton and the layout together provided a standard of living for the Indonesian people. Because each part has a philosophical meaning that can be applied to life. It further amplifies the influence of a link in islamic values that gives the essence and cultural philosophy of Java to the meaning of the architectural order of Surakarta Keraton. Some aspects of Islam and Java culture that influence the architectural meaning of Keraton Surakarta. Among them, Surakarta Keraton has a representation of human life up to god.

\section{CONCLUSION}

The conclusion of this study is the meaning of the layout of Keraton Surakarta found a region covering all activities of Keraton members. And the value of his philosophy applied to the entire town of Surakarta in general. This sense is not limited to the physical shape and layout of the part of Keraton. But it also needs to be taken into consideration further and more deeply in non-physical aspects for a more important interpretation of the ancient ancestors. Today, Surakarta Keraton architecture has the same meaning as it was originally built. But not all societies know in detail the meaning of the parts. Only a select few have personal affinity with Keraton, such as the family, the abdi dalem or the surrounding communities.

The orientation order of the Palace and its layout is a way of life for the Javanese people. Because each part has a philosophical meaning that can be applied to life. First, The 
order of the Keraton area from the north (the gladag arch) to the south (the ivory arch) as mankind's relationship with the god known as hablu minallah. Second, Keraton's position as a axis from the north-wet-west side refers to the concept of kiblat papat kalima pancer. Third, Several elements in the Keraton are created in pairs, as are public squares, kori kamandungan, kori wijil to the arch. In meaning architecture, its show to symmetrical concept. Meanwhile in philosophy meaning is everything in this world is created in multiple pairs. It means that human life is not independent of two contradictory things.

Suggestions from the results of this study are a great hope to introduce the contents and meaning of the palace with awareness and appreciation not only seen from the physical form and layout. In addition, it should also be known, understood, and carried out messages and messages that have been inserted by the predecessors through the symbols left behind. In order to become a guide through life in the world and the hereafter.

\section{REFERENCES}

$[1]$

$[2]$

5]
Sunan Kalijaga Yogyakarta, 2016. Offset, 2001. Jakarta, Indonesia: Jambatan, 1995.

[6]
D. Uswatina, “Akulturasi Budaya Jawa dan Islam, Kajian Budaya
Kirab Pusaka Malam 1 Suro di Keraton Surakarta Hadiningrat Masa Pemerintahan Paku Buwono XII," Universitas Islam Negeri

2] E. A. Setiawan, "Konsep Sevibolisme Tata Ruang Luar Keraton Surakarta," Universitas Diponegoro, Semarang, Indonesia, 2000.

3] S. Hadi, Metodologi Research. Yogyakarta, Indonesia: Andi

4] K. Koentjaraningrat, Manusia dan Kebudayaan di Indonesia.

5] Y. B. Mangunwijaya, Wastu Citra: Pengantar Ke Ilmu Budaya Bentuk Arsitektur, Sendi-Sendi Filsafatnya, Beserta ContohContoh Praktis. Jakarta, Indonesia: Gramedia Pustaka Utama, 1989.

[6] G. Broadbent, R. Bunt, and G. Jencks, Sign, Symbols and Architecture. New York: John Wiley \& Sons, 1980.

[7] C. K. Ogden, I. A. Richards, B. Malinowski, and F. G. Crookshank, The Meaning of Meaning: A Study of the Influence of Language upon Thought and the Science of Symbolism. London, UK: Routledge \& Kegan Paul, 1960.

[8] D. Febyandari, "Studi Pengaruh Konsep Lanskap Keraton Surakarta terhadap Lanskap Kota Surakarta," IPB ( Bogor Agricultural University ), Bogor, Indonesia, 2012.

[9] D. Wang and L. N. Groat, Architectural Research Methods, 2nd ed. Hoboken, New Jersey: John Wiley \& Sons, Inc, 2013. 